ISBN 978-837542-153-8

Michael Poluzhyn

NataliaVenzhynovych

Andrii Galaidin

\title{
LECTURE NOTES ON \\ HISTORIOGRAPHY OF LINGUISTICS
}

The second edition, revised and supplemented

Monograph

Czestochowa 2019 
M. Poluzhyn, N. Venzhynovych, A. Galaidin. Lecture Notes on Historiography of Linguistics: a monograph for students of philology at higher educational institutions. Czestochowa, 2019, 242 p.

Reviewers:

A. D. Belova - Doctor of Philology, Professor of Taras Shevchenko National University of Kyiv;

V.I. Karaban - Doctor of Philology, Professor of Taras Shevchenko National University of Kyiv;

M.I. Syusko - Doctor of Philology, Professor of National University of Uzhhorod.

The monograph familiarizes students, post-graduates, university lecturers and scholarly public at large with the most significant linguistic schools, basic mainstreams, up-to-date theories as well as methods of research work applied in modern language studies all over the world. A broad range of issues concerning linguistic thought development and its influence on forming current paradigms of language investigation have also been taken into account. An attempt is made to expound systematically the most essential linguo-didactic views underlying fundamental philological training of specialists in the field of learning the English language and literature. doctrines.

Assigned to all those, who are interested in general and special linguistic

$$
\begin{aligned}
& \text { Design, technical editing } \\
& \text { Prof., DSc Sergii Hushko }
\end{aligned}
$$

The publication is available in the online version on: main.nuife.org/en/educator.

The publication is assigned with a DOI number: $\mathrm{dx}$.doi.org/10.23856/W1710

\section{ISBN 978-837542-153-8}

(C) M. Poluzhyn, N. Venzhynovych, A.Galaidin

(C) Copyright by Publishing house „Educator”,

Czestochowa 2019, second supplemented edition

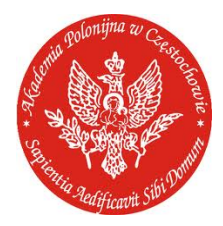

Publishing house „Educator” of Polonia University in Czestochowa,

4/6 Pułaskiego str., 42-200 Czestochowa, PL

tel: +48 (34) 368-42-15, fax: +48 (34) 324-96-62

email: wydawnictwo@ap.edu.pl, main.nuife.org/en/educator 


\section{CONTENTS}

\section{PART I EVOLUTION OF LINGUISTIC DOCTRINES}

\section{Lecture 1}

Linguistic Historiography

Lecture 2

Historical Overview of Linguistics

\section{PART II LINGUISTIC SCHOOLS}

\section{Lecture 3}

Neogrammarianism

\section{Lecture 4}

Ferdinand de Saussure and the Emergence of Structuralist Schools

Lecture 5

The Geneva School of Linguistics

\section{Lecture 6}

The Prague School of Linguistics

\section{Lecture 7}

The Copenhagen (Glossematic) and London School of Linguistics

Lecture 8

American Descriptivism

Lecture 9

The French (Sociolinguistic) School

\section{Lecture 10}

The Russian and Ukrainian Linguistic Schools

\section{PART III LINGUISTIC MAINSTREAMS}

\section{Lecture 11}

Structural Linguistics

\section{Lecture 12}

N. Chomsky's Linguistic Conception

\section{Lecture 13}

Generative-Transformational Linguistics 


\section{Lecture 14}

Discourse Analysis

\section{Lecture 15}

Text Linguistics

\section{Lecture 16}

Functional Linguistics

Lecture 17

Communicative Linguistics

Lecture 18

Sociolinguistics

Lecture 19

Cognitive Linguistics

\section{PART IV LINGUISTIC THEORIES}

\section{Lecture 20}

Linguistic Semantics

\section{Lecture 21}

Theory of Nomination

\section{Lecture 22}

Speech Act Theory

\section{Lecture 23}

Linguistic Pragmatics

\section{Lecture 24}

Ergonomic Theory

\section{Lecture 25}

Methods of Obtaining Linguistic Data 